\title{
Automatic Generation of Validated Specific Epitope Sets
}

\author{
Sebastian Carrasco Pro, ${ }^{1,2}$ John Sidney, ${ }^{2}$ Sinu Paul, ${ }^{2}$ Cecilia Lindestam Arlehamn, ${ }^{2}$ \\ Daniela Weiskopf, ${ }^{2}$ Bjoern Peters, ${ }^{2}$ and Alessandro Sette ${ }^{2}$ \\ ${ }^{1}$ Laboratorio de Bioinformática y Biología Molecular, Laboratorios de Investigación y Desarrollo, \\ Universidad Peruana Cayetano Heredia, Lima, Peru \\ ${ }^{2}$ Division of Vaccine Discovery, La Jolla Institute for Allergy and Immunology, La Jolla, CA 92037, USA \\ Correspondence should be addressed to Alessandro Sette; alex@liai.org
}

Received 24 December 2014; Accepted 2 March 2015

Academic Editor: Pedro A. Reche

Copyright (C) 2015 Sebastian Carrasco Pro et al. This is an open access article distributed under the Creative Commons Attribution License, which permits unrestricted use, distribution, and reproduction in any medium, provided the original work is properly cited.

\begin{abstract}
Accurate measurement of $\mathrm{B}$ and $\mathrm{T}$ cell responses is a valuable tool to study autoimmunity, allergies, immunity to pathogens, and host-pathogen interactions and assist in the design and evaluation of $\mathrm{T}$ cell vaccines and immunotherapies. In this context, it is desirable to elucidate a method to select validated reference sets of epitopes to allow detection of T and B cells. However, the evergrowing information contained in the Immune Epitope Database (IEDB) and the differences in quality and subjects studied between epitope assays make this task complicated. In this study, we develop a novel method to automatically select reference epitope sets according to a categorization system employed by the IEDB. From the sets generated, three epitope sets (EBV, mycobacteria and dengue) were experimentally validated by detection of $\mathrm{T}$ cell reactivity ex vivo from human donors. Furthermore, a web application that will potentially be implemented in the IEDB was created to allow users the capacity to generate customized epitope sets.
\end{abstract}

\section{Introduction}

Adaptive immunity is based on the recognition of specific molecular structures, named epitopes, by either antibodies/B cell receptors or T cell receptors. Antibodies and B cell receptors bind a wide variety of structures, including proteins and carbohydrates. In the case of protein ligands, antibodies can recognize either a series of contiguous residues (linear epitopes) or a set of residues encoded in disparate regions of the protein sequence and brought together in the three dimensional structure of the protein ligand (discontinuous epitopes).

$\mathrm{T}$ cells recognize a complex between MHC molecules (named HLA in humans and H-2 in mouse) and, in most cases, a peptidic epitope of $8-16$ residues in length $[1,2]$. T cell responses are a key component of adaptive immunity. In concert with antibody responses, CD8 T cells, recognizing class I binding epitopes, and CD4 T cells, recognizing their class II counterparts, are key players in immunity to viruses and bacteria [3]. In the case of allergic reactions, CD4 T cell responses play a key role in pathogenesis both directly and indirectly through the regulation of antibody responses of the Ig E class [4].

Accurate measurement of $\mathrm{B}$ and $\mathrm{T}$ cell responses is a valuable tool to study autoimmunity, allergies, immunity to pathogens, and host-pathogen interactions and assist in the design and evaluation of $\mathrm{T}$ cell-based vaccines and immunotherapies [5-8]. Accordingly, a large number of studies have been devoted to defining B and T cell epitopes, a process that has been facilitated by an ever-increasing expansion and refinement of experimental methods.

As immune investigations proceed over time, many different epitopes from various organisms have been identified. Alternatively, large-scale epitope identification can reveal hundreds of potential epitopes [9-12]. The Immune Epitope Database (IEDB) $[13,14]$ is a freely available resource that serves as a repository of experimentally derived immune epitope information available in the peer-reviewed published literature, as well as from direct submission from NIH-NIAID funded large-scale epitope identification studies. The IEDB content covers a broad range of indications, to include infectious diseases (excluding HIV), allergies, transplantation, and 
autoimmune disease and a similarly broad range of hosts, including humans, nonhuman primates, mice, and livestock, amongst others. The database, as of October 2014, hosts experimental data related to 121,812 different peptidic epitope structures.

This large amount of information might, in some cases, pose a challenge for the identification and selection of appropriate sets of epitopes for use in specific contexts. Thus, it is clearly desirable, given the ever-growing body of information contained in the IEDB, to develop tools to enable the efficient generation of sets of validated reference epitopes for any antigenic source of interest.

While an epitope, according to classic definitions, is any structure capable of interacting with $\mathrm{T}$ and $\mathrm{B}$ cell receptors, in practice the consensus in the scientific community is that certain types of assays identify the most relevant and validated epitopes. In the context of antibody reactivity, by way of example, epitopes identified on the basis of X-ray structures of Ag/antibody complexes, biological activity, and in vivo assays or recognized by $\operatorname{IgE}$ in the case of allergens are considered more biologically relevant than linear epitopes recognized in ELISA assays and elicited by peptide immunization. In the case of $\mathrm{T}$ cell reactivity, again by way of example, multimer/tetramer staining assays or readouts based on ICS or ELISPOT assays, are preferred over older assay platforms such as Thymidine incorporation following multiple in vitro restimulations with peptides. These high quality assays have been selected based on our experience and judgment; however, in the web tool developed, the user will be capable of customizing it by his/her needs, that is, select only epitopes derived from neutralization or ELISA assays or any other desired selection.

Indeed, for many applications, it is desirable to study $\mathrm{T}$ cells ex vivo, without manipulation. This is because manipulations, such as in vitro expansion, are known to profoundly change the phenotype and characteristic of the T cells [1517], thus questioning the physiological relevance of some of the experimental observations. However, direct ex vivo detection of human $\mathrm{T}$ cell responses is often difficult, largely because the immune response in any individual may target many different epitopes, and different individuals typically recognize unique epitope repertoires. Simultaneous use of many different epitopes as a pool might represent a powerful approach to detecting $\mathrm{T}$ cell responses, because even if the frequency of $\mathrm{T}$ cells recognizing each individual epitope may be below the limit of detection, a pool of a large number of epitopes (i.e., responses) might pass the limit of detection.

An important consideration in the definition of reference sets of epitopes is how to factor the number of individual donors or experiments in which a given structure is reported to elicit a positive response, and particularly if this validation is provided in multiple independent studies. For example, different studies often report on essentially the same epitope but utilize different nested, truncated, or frame-shifted version of the same sequence, leaving uncertainty on how to combine the data or which particular version of the epitope to select for testing. Clarification of a general approach for combining data from such disparate studies would greatly facilitate the generation of nonredundant sets of epitopes.
In the present study, we have attempted the definition of an automated process to generate reference sets of high quality epitopes for various disease indications. The resulting tool, made available to the scientific community, provides a standardized and reproducible platform to automatically extract and process relevant data from the IEDB without the need of complex analysis and judgment calls from the user. At the same time, the tool also offers flexibility to enable the end user to design sets meeting specific user-defined criteria. We have also analyzed the data currently available in the IEDB, to determine how many sets of pathogen or autoantigen specific epitopes could be identified on the basis of the data available to date.

\section{Materials and Methods}

2.1. Database, Processing, and Implementation. Epitope data was derived from the IEDB database as of October 2014. MySQL was used to run queries and directly work with the database itself. The web page application is written in PHP/HTML code with a MySQL connection that allows communication between the database and the user interface.

\subsection{Ranking Scores on the Basis of Response Frequency and} Assay Type. Two independent scoring systems were developed to allow ranking and sorting of the epitopes. The first was based on the type of assays used to characterize the epitopes and the second on the frequency by which each epitope was recognized.

Regarding the assay type scoring system for MHC class I or class II epitopes, in our selection we included epitopes defined by multimer/tetramer staining, ELISPOT, and ICS assays. We arbitrarily associate a numerical parameter value of 3,2 , and 1 to these assay types, respectively. Each of these assay types can be used in either an ex vivo or in vitro configuration. To provide that ex vivo assays are always ranked higher, we assigned an ex vivo configuration a value of 4 , and an in vitro configuration a value of 1 , and calculated a final assay score by multiplying the assay type and configuration values. In the case of B cell epitopes, X-ray structure, biological activity, and in vivo assays were assigned a score of 1 , as well as epitopes that present IgE; for these epitopes, the effector origin was not taken in consideration. Since each epitope can be associated with multiple records, each describing different assays and thus with different assay scores, the highest assay score, reflecting the highest level of validation reached for that epitope, was selected and carried forward.

In terms of scoring each epitope on the basis of the frequency by which it was recognized, we utilized a previously described Response Frequency (RF) score [18]. The RF score is calculated as

$$
\frac{R-\sqrt{R}}{N}
$$

where $N$ is the total of subjects tested and $R$ is the number of positive responses. The square root is a correction factor, approximating one standard deviation for the number of 
responding donors. This gives a higher score to epitopes studied with larger sample sizes. In case there is no information of subjects tested, the epitope will be assigned $R=1, N=1$ if the assay outcome is positive and $R=0, N=1$ if it was negative. The RF score (RFS) also takes into account all data for a given epitope across all publications. We decided to use an older and simpler RF definition, as compared to the one used in [19], as it is more suitable to filter epitopes based on their RFS. As an example, consider an epitope 1 with positive responses $(P)=1$ and total subjects $(T)=1$; the new definition gives a RFS $=1(0.04-1.00)$ whereas the older version gives an RFS = 0 . In contrast with epitope 2 with $P=8$ and $T=11$, the new version gives $\mathrm{RFS}=0.73(0.43: 0.92)$ and the older $\mathrm{RFS}=0.47$. In order for the RFS to reflect the difference between epitopes 1 and 2 in terms of the total number of subjects, the latter should be assigned a higher score to be used for ranking and filtering the data, which at the end benefits the user giving simpler and useful results.

Both the assay score and RF score are calculated for each epitope and provided in the results. This allows further ranking or selecting epitopes based on different thresholds for these criteria.

2.3. Generation of Consensus Sequences for Overlapping and Nested MHC Class I and Class II Epitopes. For MHC class I epitopes, it is generally observed that a length of about 8-11 residues is optimal for $\mathrm{T}$ cell recognition and use in assays. Because of the structure of the class I binding groove, distinct class I sequences typically represent unique epitopes, even if they are nested within a longer sequence that is also recognized by $\mathrm{T}$ cells. Accordingly, for the present study, we have not subjected class I epitopes of nested or overlapping character to further processing.

For MHC class II epitopes, however, optimal epitopes are usually longer than the minimal $\mathrm{T}$ cell recognized 9mer core. In general, class II epitopes are optimally of 13-20 residues in length [1]. Peptides of varying length but that carry the same core may all be similarly active and/or recognized by the same $\mathrm{T}$ cell specificity. Thus, many of the epitope structures contained in the IEDB for class II epitopes are redundant, nested or largely overlapping. For this reason, it is desirable to devise strategies to reduce the complexity of class II epitope sets. Here, we developed a clustering algorithm to generate consensus sequences or cluster of epitopes, an illustration of such a process can be found in Table 1. In order to solve this problem, our approach first sorts the peptides based on their RF scores. Then, taking the highest ranked peptide as starting sequence, we move down the ranked list aligning the sequences to find nested or overlapping epitopes by at least 9 residues. For this approach, we only consider identical matches over the region of overlap and identical nested peptides; given this definition, mismatches will be treated as separate epitopes. When a nested peptide is found, we will keep only the larger peptide and calculate a new RF score using the sum of all responded and tested subjects per epitope in the cluster. For overlapping epitopes, a consensus epitope or cluster will be generated combining the sequences, if the cluster length is up to 20 residues. In these cases, the RF
TABLE 1: Example of a dataset reduction of MHC class II epitopes.

(a) Epitopes before being processed by the clustering tool; epitopes forming a potential consensus sequence or cluster are in bold

\begin{tabular}{lcc}
\hline Epitope/cluster & RF score & Assay score \\
\hline MLVLLVAVLVTAVYAFVHA & 0.67 & 8 \\
IQGNVTIHSLLDEGK & $\mathbf{0 . 6 6}$ & $\mathbf{8}$ \\
VPSPSMGRDIKVQFQSGGAN & 0.65 & 12 \\
NVTSIHSLLDEGKPT & 0.63 & 12 \\
QGNVTIHSLLDEGKPT & $\mathbf{0 . 5 9}$ & $\mathbf{1 2}$ \\
AQAAVVRFQEAANKQKQELD & 0.47 & 12 \\
GNVTSIHSLLDEG & $\mathbf{0 . 4 6}$ & $\mathbf{4}$ \\
FAGIEAAASAIQGNV & 0.42 & 12 \\
\hline
\end{tabular}

(b) The cluster generated by combining the sequences and associated information is in bold

\begin{tabular}{lcc}
\hline Epitope/cluster & RF score & Assay score \\
\hline MLVLLVAVLVTAVYAFVHA & 0.67 & 8 \\
VPSPSMGRDIKVQFQSGGAN & 0.65 & 12 \\
IQGNVTIHSLLDEGKPT & $\mathbf{0 . 5 7}$ & $\mathbf{1 2}$ \\
AQAAVVRFQEAANKQKQELD & 0.47 & 12 \\
FAGIEAAASAIQGNV & 0.42 & 12 \\
\hline
\end{tabular}

score will be calculated as a new RF score as in the nested case. For the assay type scoring system, the highest ranked assay and application of all the assays associated with the set of nested epitopes will be considered.

2.4. Human Study Subjects. In the case of donors with latent tuberculosis infection (LTBI), leukapheresis or whole unit blood samples from 10 adults were obtained from the University of California, San Diego, Antiviral Research Center (AVRC) clinic. Donors were classified as LTBI based on positive QuantiFERON-TB Gold In-Tube (Cellestis), as well as a physical exam and/or chest X-ray that was not consistent with active tuberculosis. Because Dengue virus (DENV) prevalence is low in the San Diego area, most LTBIs are DENV naïve.

To obtain DENV seropositive samples, anonymous blood donations from healthy adults were obtained by the National Blood Center, Ministry of Health, in the area of Colombo, Sri Lanka. Plasma of the associated donation was tested for serology using the flow-based U937+DC-SIGN neutralization assay (conducted at the University of North Carolina, Chapel Hill) as previously described [11, 20]. Because TB prevalence is low in the Colombo area, most DENV seropositive donors can be assumed to be TB negative.

All Samples were collected and used following guidelines from the Institutional Review Boards (IRB) of LJI and the Medical Faculty, University of Colombo (serving as National Institutes of Health-approved IRB for Genetech Research Institute).

2.5. Peptides and PBMC Isolation. 15-mer peptides were synthesized as crude material on a small $(1 \mathrm{mg})$ scale by Mimotopes (Victoria, Australia) and/or A and A (San Diego). 
PBMCs were purified by density gradient centrifugation (Ficoll-Hypaque, Amersham Biosciences) from $100 \mathrm{~mL}$ of leukapheresis sample or $450 \mathrm{~mL}$ of whole blood, according to manufacturer's instructions. Cells were cryopreserved in liquid nitrogen suspended in fetal bovine serum (Gemini Bio-products) containing 10\% dimethyl sulfoxide.

2.6. Intracellular Cytokine Staining (ICS). PBMCs $\left(2 \times 10^{6}\right.$ cells/well) were incubated with peptide pools $(1 \mu \mathrm{g} / \mathrm{mL})$ for $2 \mathrm{hrs}$. Brefeldin A (1 $\mu \mathrm{g} / \mathrm{mL})$ (BD Bioscience) was added to the mixture and incubated for another 4 hours (i.e., a total of $6 \mathrm{hrs}$ with peptide). Cells were then washed and stained for cell surface markers using anti-CD3-Alexa Fluor 700 (UCHT1), anti-CD8-V500 (RPA-T8) (both from BD Biosciences), antiCD4-APC EFluor780 (RPA-T4), anti-CD45RA-EFluor450 (HI100), and anti-CCR7(CD197)-PerCPCy5.5 (G043H7) (all three from Affymetrix eBioscience) for 30 mins on ice. Cells were then washed, fixed with $4 \%$ paraformaldehyde, blocked with human sera, and stained for intracellular IFN $\gamma$ using anti-IFN $\gamma$-FITC (4S.B3, Affymetrix eBiosciences). Samples were acquired on a BD LSR II flow cytometer. The frequency of cells responding to the TB/DENV-specific peptides was quantified by determining the total number of gated subset+ and cytokine+ cells and background values subtracted (as determined from the medium alone control) using FlowJo software (Tree Star).

\section{Results and Discussion}

3.1. Filtering Datasets to Select Human Peptidic Epitopes of Appropriate Size, Defined Restriction, and Assay Type. As a preliminary step towards deriving sets of reference epitopes associated with preferred validated assays, we processed the data contained in the IEDB relating to T cell epitopes. As of October 2014, a total of 28370 epitopes are associated with positive results in at least one T cell assay.

As an example of filtering strategies, we first considered only peptidic epitopes associated with infectious agents and allergies (Figure 1) and initially focused on bacteria, viruses, and nonhuman eukaryotes as epitope sources. Next, we only considered data in which humans were the host of the immune response and for which data was available to allow specifically characterizing responses as either class I or class II restricted. In the case of class I, we further considered only epitopes of 8-11 residues, and in the case of class II, only peptides of 13-20 residues were considered.

The next step in our process was to filter the results further by selecting epitopes that have been tested in "high quality" assays. This is possible because the IEDB curates the specific assays that are used to define and characterize the specific epitopes reported in the literature or provided to the database by direct submission. While obviously any desired assay set could be used, here we selected for inclusion the multimer/tetramer staining, ELISPOT and ICS assays. This assay-based filtering resulted in a final total of 6345 epitopes, 2512 and 3833 for class I and class II epitopes, respectively (Figure 1), representing about $20 \%$ of the initial 28370 epitopes.

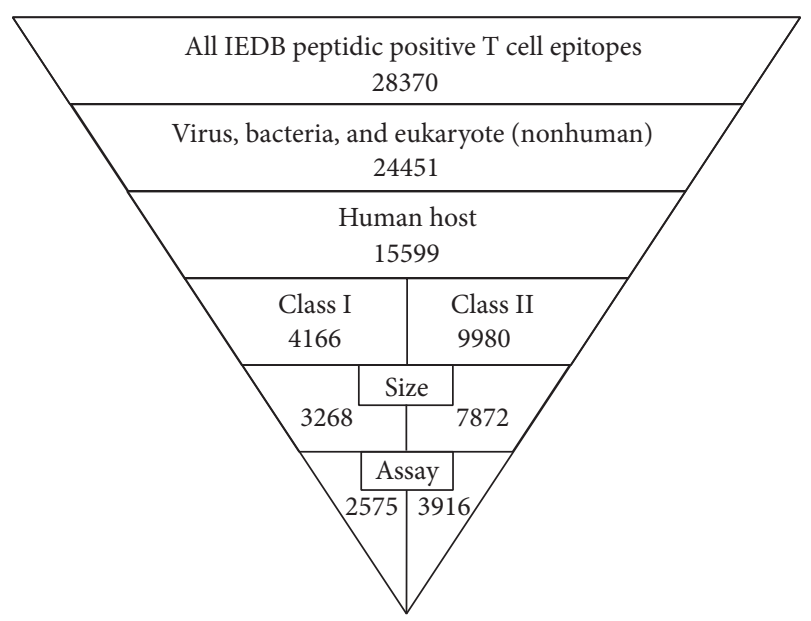

FIGURE 1: Diagram of the filtering steps towards the generation of the validated sets of epitopes, including the number of epitopes found in each step.

3.2. Identification of Epitope Categories Supported by Current IEDB Data. We surveyed the epitope data in the IEDB in terms of the species and antigens of provenance (epitope sources). For this purpose we adapted the categorization adopted by Seymour et al. [21]. The relative population of these categories in the IEDB as of the 2009 date was discussed by Davies et al. [22].

In Table 2, we list 43 categories for which at least ten class I or class II epitopes were identified for viruses/bacteria (Table 2(a)), nonhuman eukaryotes (Table 2(b)), and autoantigens (Table 2(c)). The data were further classified according to the source organism of the epitope. The number of epitopes contained in each category is also listed in Table 2. The table also lists B cell epitopes as identified and discussed further below.

3.3. Definition of Epitope Tables. As a result of the processes described above, we generated sets of epitopes for the various categories. As an example, Table 3 details the 21 epitopes defined for the Parvoviridae human class I category. In addition to the epitope sequence, source organism and protein, and $\mathrm{MHC}$ restriction, the IEDB Epitope ID is provided to facilitate retrieval of additional information from the IEDB pertaining to the epitope. Finally, the Response Frequency, Assay Score, the types of assay, and effector origin (ex vivo or in vitro), utilized to derive the Assay Score, are also given. All epitope tables from the categories shown in Table 2 can be found in the supplemental file "Epitope Tables.zip" in the Supplementary Material available online at http://dx.doi.org/10.1155/2015/763461.

3.4. Expanding the Tool to Address Autoimmune Epitopes, $B$ Cell Epitopes, and Murine Epitopes. Having established the conceptual framework for selection of epitope sets, we next expanded our applicability. Autoimmune epitopes are identified by the fact that both source antigen and host organism are the same (e.g., both the T cells and the epitope 
TABLE 2: (a) Number of epitopes per category for viruses and bacteria. (b) Number of epitopes per category for eukaryotes (nonhuman). (c) Number of epitopes per category for autoimmune epitopes (human and mouse).

(a)

\begin{tabular}{|c|c|c|c|c|c|c|c|c|}
\hline & \multirow{2}{*}{\multicolumn{2}{|c|}{ Class I }} & \multirow{2}{*}{\multicolumn{2}{|c|}{ Class II }} & \multicolumn{4}{|c|}{ B cell } \\
\hline & & & & & \multicolumn{2}{|c|}{ Linear } & \multicolumn{2}{|c|}{ Discontinuous } \\
\hline & HLA & $\mathrm{H}-2$ & HLA & $\mathrm{H}-2$ & Human & Mouse & Human & Mouse \\
\hline \multicolumn{9}{|l|}{ Virus } \\
\hline \multicolumn{9}{|l|}{ ssRNA (-) strand virus } \\
\hline H1N1 subtype influenza A & 41 & 77 & 207 & 206 & & 15 & 11 & 27 \\
\hline H3N2 subtype influenza A & 18 & 18 & 92 & 17 & & 11 & 22 & 81 \\
\hline $\begin{array}{l}\text { Other influenza A subtypes } \\
\text { (not H3N2 or H1N1) }\end{array}$ & 116 & 43 & 179 & 25 & & 43 & 16 & 81 \\
\hline Influenza B/C & & & 13 & & & & & 36 \\
\hline $\begin{array}{l}\text { Paramyxoviridae } \\
\text { (respiratory syncytial } \\
\text { virus, measles, mumps) }\end{array}$ & 47 & 80 & 28 & 27 & & 33 & & 71 \\
\hline Hantavirus & 14 & & & & & & & \\
\hline \multicolumn{9}{|l|}{ ssRNA (+) strand virus } \\
\hline Dengue virus & 432 & 116 & 58 & 139 & & 24 & 29 & 97 \\
\hline Hepatitis $\mathrm{C}$ virus & 405 & 65 & 241 & 20 & 53 & 32 & 27 & 12 \\
\hline West Nile virus & 33 & & 99 & 103 & & & & 24 \\
\hline Yellow fever & 18 & 34 & 94 & 118 & & & & \\
\hline Japanese encephalitis virus & & & 33 & & & & & \\
\hline $\begin{array}{l}\text { Picornaviridae (coxsackie, } \\
\text { hepatitis A) }\end{array}$ & 14 & 12 & & 52 & & 77 & & 94 \\
\hline Coronaviruses & 22 & 38 & 38 & 25 & 23 & 28 & & 27 \\
\hline \multicolumn{9}{|l|}{ Retrotranscribing virus } \\
\hline Hepatitis B virus & 59 & 72 & 38 & 18 & & 13 & & \\
\hline Deltaretrovirus (HTLV) & 25 & & & & & & & \\
\hline \multicolumn{9}{|l|}{ dsDNA virus } \\
\hline Adenoviruses & 13 & & 45 & & & 10 & & \\
\hline $\begin{array}{l}\text { Alphaherpesvirinae } \\
\text { (human herpesvirus } 1 / 2 \text {, } \\
\text { Varicellovirus) }\end{array}$ & 91 & 52 & 35 & 13 & & 32 & & 32 \\
\hline $\begin{array}{l}\text { Betaherpesvirinae (CMV, } \\
\text { human herpesvirus 5, } \\
\text { roseolovirus, murid } \\
\text { herpesvirus) }\end{array}$ & 204 & 48 & 141 & 20 & & & & \\
\hline $\begin{array}{l}\text { Gammaherpesvirinae } \\
\text { (Epstein-Barr virus, } \\
\text { Rhadinovirus, human } \\
\text { herpesvirus 4) }\end{array}$ & 237 & 63 & 59 & & & & & \\
\hline $\begin{array}{l}\text { Papillomaviridae } \\
\text { (human papillomavirus) }\end{array}$ & 80 & 44 & 72 & & & 30 & & \\
\hline Poxviridae (vaccinia, pox) & 228 & 343 & 76 & 30 & & & & \\
\hline $\begin{array}{l}\text { Polyomavirus } \\
\text { (Simian vacuolating virus) }\end{array}$ & 31 & 14 & & & & & & \\
\hline Parvoviridae & 21 & & 24 & & 10 & & & \\
\hline \multicolumn{9}{|l|}{ Bacteria } \\
\hline \multicolumn{9}{|l|}{ Actinobacteria/proteobacteria } \\
\hline $\begin{array}{l}\text { Alphaproteobacteria } \\
\text { (Rhizobiales, Rickettsia, } \\
\text { and Anaplasmas) }\end{array}$ & & & 31 & & & & & \\
\hline $\begin{array}{l}\text { Betaproteobacteria } \\
\text { (Neisseria, Bordetella, and } \\
\text { Burkholderia) }\end{array}$ & & & 324 & 158 & & 33 & & \\
\hline Mycobacterium & 129 & 33 & 478 & 33 & & & & 11 \\
\hline
\end{tabular}


(a) Continued.

\begin{tabular}{|c|c|c|c|c|c|c|c|c|}
\hline & \multirow{2}{*}{\multicolumn{2}{|c|}{ Class I }} & \multirow{2}{*}{\multicolumn{2}{|c|}{ Class II }} & \multicolumn{4}{|c|}{ B cell } \\
\hline & & & & & \multicolumn{2}{|c|}{ Linear } & \multicolumn{2}{|c|}{ Discontinuous } \\
\hline & HLA & $\mathrm{H}-2$ & HLA & $\mathrm{H}-2$ & Human & Mouse & Human & Mouse \\
\hline \multicolumn{9}{|l|}{ Firmicutes/other bacteria } \\
\hline Chlamydiales (chlamydia) & 15 & 38 & & & & 37 & & \\
\hline Clostridiales & & & 70 & & & & & \\
\hline $\begin{array}{l}\text { Other Bacilli } \\
\text { (anthracis, cereus, } \\
\text { Geobacillus, and } \\
\text { Enterococcus) }\end{array}$ & & & 106 & & & 19 & & \\
\hline
\end{tabular}

(b)

\begin{tabular}{|c|c|c|c|c|c|c|c|c|}
\hline & \multirow{2}{*}{\multicolumn{2}{|c|}{ Class I }} & \multirow{2}{*}{\multicolumn{2}{|c|}{ Class II }} & \multicolumn{4}{|c|}{ B cell } \\
\hline & & & & & \multicolumn{2}{|c|}{ Linear } & \multicolumn{2}{|c|}{ Discontinuous } \\
\hline & HLA & $\mathrm{H}-2$ & HLA & $\mathrm{H}-2$ & Human & Mouse & Human & Mouse \\
\hline \multicolumn{9}{|l|}{ Alveolata } \\
\hline $\begin{array}{l}\text { Plasmodium (P. falciparum, } \\
\text { P. vinckeia, and P. yoelli) }\end{array}$ & 64 & 29 & 186 & 33 & 16 & 49 & & \\
\hline \multicolumn{9}{|l|}{ Euglenozoa } \\
\hline $\begin{array}{l}\text { Trypanosomatidae } \\
\text { (Trypanosoma, Leishmania) }\end{array}$ & 91 & 30 & & 14 & & & & \\
\hline \multicolumn{9}{|l|}{ Fungi } \\
\hline Aspergillus & & & 50 & 50 & 73 & & & \\
\hline Other fungi & & & 77 & & 54 & 11 & & \\
\hline \multicolumn{9}{|l|}{ Plants } \\
\hline $\begin{array}{l}\text { Fabaceae (peas, } \\
\text { soybean, peanut family) }\end{array}$ & & & 17 & & 419 & & & \\
\hline Betulaceae (birch family) & & & 30 & & 24 & & & \\
\hline $\begin{array}{l}\text { Cupressaceae (cypress, } \\
\text { cedar family) }\end{array}$ & & & 21 & & 22 & & & \\
\hline $\begin{array}{l}\text { Gluten, coeliac } \\
\text { Disease }^{1}\end{array}$ & & & 23 & & 245 & 36 & & \\
\hline Timothy-grass & & & 474 & & 19 & & & \\
\hline Other grass & & & 98 & & 124 & & & \\
\hline Amaranthaceae & & & 20 & & & & & \\
\hline \multicolumn{9}{|l|}{ Animals } \\
\hline Insects & & & 67 & & 23 & & & \\
\hline Arachnid & & & 97 & & 33 & 13 & 14 & \\
\hline Mammals & & 119 & 41 & 69 & 707 & 80 & & 15 \\
\hline \multicolumn{9}{|c|}{$\begin{array}{l}{ }^{1} \text { Only epitopes derived from gliadin protein and high molecular weight glutenin [23] were included. } \\
\text { (c) }\end{array}$} \\
\hline & \multicolumn{2}{|c|}{ Class I } & \multicolumn{2}{|c|}{ Class II } & \multicolumn{4}{|c|}{ B cell } \\
\hline & & & & & \multicolumn{2}{|c|}{ Linear } & \multicolumn{2}{|c|}{ Discontinuous } \\
\hline & HLA & $\mathrm{H}-2$ & HLA & $\mathrm{H}-2$ & Human & Mouse & Human & Mouse \\
\hline Rheumatoid arthritis & 27 & & 11 & & & & & \\
\hline Diabetes & 73 & 76 & 46 & 17 & & & & \\
\hline Multiple sclerosis & & & 11 & & 13 & & & \\
\hline
\end{tabular}




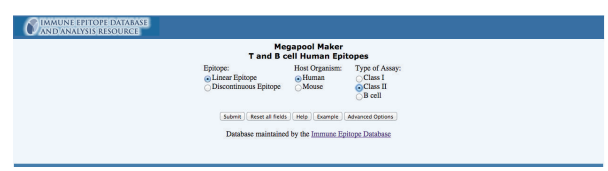

(a)

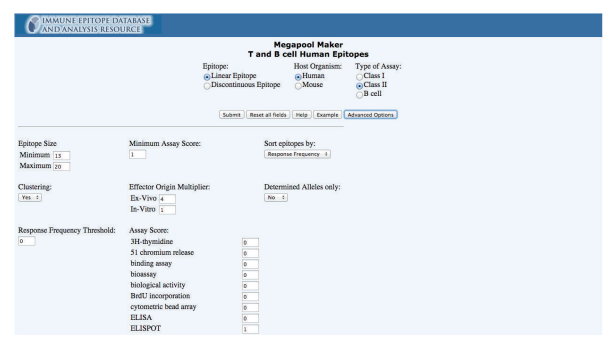

(b)

FIgURE 2: (a) Web application main page interface. (b) Web application "advanced options" page interface.

are originated from a human source). As listed in Table 2(c), all autoimmunity epitope categories relevant to a given disease are condensed into a single category. A protein tree functionality available on the IEDB [14] and a list of the most common antigens associated with each disease were used to extract autoimmune epitopes. The identified categories for which at least ten class I or class II epitopes were available are listed in Table 2(c), along with the number of epitopes contained in each category.

We considered expanding the scope of the study to also select epitopes recognized by species other than humans. In this case, the second most frequently represented host species is mouse. Accordingly, an option was created in the web application (next section) to allow selection of murine epitopes. The number of murine epitopes identified is listed as a separate column in Table 2.

Finally, we also expanded our analysis to allow selection of B cell/antibody epitopes. In this case, we set a 5 to 20 residue size window and initially selected X-ray structure, biological activity, and in vivo assays as most biologically relevant. In addition, we included induction of IgE subclass responses, as this type is most relevant in the context of allergic diseases. The number of $\mathrm{B}$ cell epitopes identified accordingly is also listed as a separate column in Table 2.

\subsection{Implementation of a Web Application to Automatically} Generate Epitope Sets. Finally, we developed a tool, which will be hosted by the IEDB as an additional link in the search results page and will be part of the next IEDB update release in fall 2015. This tool allows generation of specific epitope sets following the default criteria described above but also allows users to customize the generation of novel sets.

A sample screen shot of the main interface is shown in Figure 2(a). The main interface automatically obtains query results from IEDB searches and adds them to the query parameters of the tool. There, the user may choose to generate sets of class I, class II, antibody linear, or antibody discontinuous epitopes, relating to either human or mouse as the host organism from which the epitopes are derived. Because of the flexibility of the design, additional host organisms may be included, provided sufficient data becomes available in the literature. The user is offered results obtained with the default settings.

An "advanced options" webpage can be accessed from the main page, and a sample screen shot of this option is shown in Figure 2(b). In the advanced options, the user can set their custom RF score threshold and Assay score threshold, rank the results using the RF score or Assay Score, include the clustering tool, filtering by determined alleles (known MHC allele), and set the minimum and maximum size if the epitopes. Also, a number of additional assays, generally considered as being less rigorous, are provided, allowing the user to set custom parameters. Every field in the advance options dynamically changes to fit the default values for a given query. For example, if the user selects MHC class II epitopes, the web tool will set the clustering field to "yes" and the epitope size to 13-20.

3.6. Selection and Synthesis of Peptide Sets for Experimental Validation. To experimentally validate the usefulness of the tool we decided to synthesize some of the actual peptide sets identified by the tool and experimentally test them for recognition by human $\mathrm{T}$ cell responses. One of the main challenges for testing large pools for $\mathrm{T}$ cell recognition is that ex vivo $\mathrm{T}$ cells assays require relatively substantial amounts of each epitope (in the 1-0.1 microgram $/ \mathrm{mL}$ range), compounded by the fact that peptide solubility in solvents most widely applicable to preparing peptide stock solutions, such as DMSO, is usually limited to about $20-40 \mathrm{mg} / \mathrm{mL}$. Since solvents like DMSO are toxic in cellular assays at concentrations above $0.5 \%$, this would seem to effectively limit the number of peptides that can be safely included in a pool to about 20 .

However, in many cases the solubility of one peptide is not drastically influenced by the presence of other peptides (especially if the sequences, isolectric point, and general solubility are different). For this reason, we predicted that it might be possible to make pools of peptides already dissolved in a solvent like DMSO, mix the solutions, and relyophilize the pool of pools. Indeed, we routinely find these "sequentially lyophilized" pools, once resuspended, to be much more soluble than the individual components.

Accordingly, we synthetized a set of 207 EBV human CD8/class I epitopes, identified by the default setting described above (Supplemental Table 1A). In addition, we also synthetized a set of $92 \mathrm{CD} 8 /$ class I epitopes derived from DENV virus, obtained by selecting only peptides with $\mathrm{RF}>=0.01$ (Supplemental Table 1B), and a set of 86 epitopes CD4/class II epitopes derived from Mycobacterium tuberculosis, based on an RF score $>=0.1$ and being recognized ex vivo (Supplemental Table 1C).

\subsection{Experimental Validation of the Use of Reference Epitope} Sets to Detect T Cell Reactivity Ex Vivo. Peptides corresponding to these three sets of epitopes were pooled and tested with human PBMC as a source of T cells. For these experiments 
TABLE 3: Parvoviridae virus validated epitope set downloaded from the web tool.

\begin{tabular}{|c|c|c|c|c|c|c|c|c|}
\hline Epitope/cluster & Epitope ID & $\begin{array}{c}\text { Source } \\
\text { organism }\end{array}$ & $\begin{array}{l}\text { Source } \\
\text { protein }\end{array}$ & $\begin{array}{c}\text { MHC } \\
\text { restriction }\end{array}$ & RF score & Assay score & Assay type & $\begin{array}{l}\text { Effector } \\
\text { origin }\end{array}$ \\
\hline FYTPLADQF & 18474 & $\begin{array}{c}\text { Human } \\
\text { parvovirus } \\
\text { B19 }\end{array}$ & $\begin{array}{l}\text { Noncapsid } \\
\text { protein NS-1 }\end{array}$ & HLA-A*24:02 & 0.51 & 12 & $\begin{array}{l}\text { Multimer/tetramer, } \\
51 \text { chromium, } \\
\text { ELISPOT }\end{array}$ & $\begin{array}{l}\text { Direct ex } \\
\text { vivo, cell } \\
\text { line/clone }\end{array}$ \\
\hline GLCPHCINV & 20786 & $\begin{array}{l}\text { Human } \\
\text { parvovirus } \\
\text { B19 }\end{array}$ & $\begin{array}{c}\text { Noncapsid } \\
\text { protein NS-1 }\end{array}$ & $\begin{array}{c}\text { HLA- } \\
\text { A }^{*} 02: 01 \\
\text { HLA-A2 }\end{array}$ & 0.46 & 4 & $\begin{array}{l}\text { ELISPOT, } 51 \\
\text { chromium }\end{array}$ & Direct ex vivo \\
\hline QPTRVDQKM & 51981 & $\begin{array}{l}\text { Human } \\
\text { parvovirus } \\
\text { B19 }\end{array}$ & $\begin{array}{c}\text { Noncapsid } \\
\text { protein NS-1 }\end{array}$ & HLA-B35 & 0.29 & 3 & $\begin{array}{c}\text { ELISPOT, } 51 \\
\text { chromium, } \\
\text { multimer/tetramer }\end{array}$ & $\begin{array}{c}\text { Cell } \\
\text { line/clone }\end{array}$ \\
\hline LLHTDFEQV & 37397 & $\begin{array}{l}\text { Human } \\
\text { parvovirus } \\
\text { B19 }\end{array}$ & $\begin{array}{c}\text { Noncapsid } \\
\text { protein NS-1 }\end{array}$ & $\begin{array}{l}\text { HLA- } \\
\text { A }^{*} 02: 01 \\
\text { HLA-A2 }\end{array}$ & 0.21 & 4 & $\begin{array}{c}\text { ELISPOT, } 51 \\
\text { chromium }\end{array}$ & Direct ex vivo \\
\hline TAKSRVHPL & 62900 & $\begin{array}{l}\text { Human } \\
\text { parvovirus } \\
\text { B19 }\end{array}$ & $\begin{array}{c}\text { Viral protein } \\
2\end{array}$ & HLA-B8 & 0.12 & 4 & $\begin{array}{c}\text { ELISPOT, } 51 \\
\text { chromium }\end{array}$ & Direct ex vivo \\
\hline TEADVQQWL & 63285 & $\begin{array}{l}\text { Human } \\
\text { parvovirus } \\
\text { B19 }\end{array}$ & $\begin{array}{c}\text { Noncapsid } \\
\text { protein NS-1 }\end{array}$ & HLA-B40 & 0.1 & 4 & $\begin{array}{l}\text { ELISPOT, } 51 \\
\text { chromium }\end{array}$ & Direct ex vivo \\
\hline SSHSGSFQI & 61077 & $\begin{array}{l}\text { Human } \\
\text { parvovirus } \\
\text { B19 }\end{array}$ & $\begin{array}{c}\text { Noncapsid } \\
\text { protein NS-1 }\end{array}$ & HLA-Class I & 0 & 4 & $\begin{array}{c}\text { ELISPOT, } 51 \\
\text { chromium }\end{array}$ & Direct ex vivo \\
\hline SESSFFNLI & 57628 & $\begin{array}{l}\text { Human } \\
\text { parvovirus } \\
\text { B19 }\end{array}$ & $\begin{array}{c}\text { Noncapsid } \\
\text { protein NS-1 }\end{array}$ & HLA-B40 & 0 & 4 & ELISPOT & Direct ex vivo \\
\hline VQQWLTWCN & 70634 & $\begin{array}{l}\text { Human } \\
\text { parvovirus } \\
\text { B19 }\end{array}$ & $\begin{array}{c}\text { Noncapsid } \\
\text { protein NS-1 }\end{array}$ & HLA-Class I & 0 & 4 & $\begin{array}{l}51 \text { chromium, } \\
\text { ELISPOT }\end{array}$ & Direct ex vivo \\
\hline VPQYGYLTL & 70458 & $\begin{array}{l}\text { Adeno- } \\
\text { associated } \\
\text { virus - } 2\end{array}$ & $\begin{array}{l}\text { Major coat } \\
\text { protein VP1 }\end{array}$ & HLA-B* 07:02 & 0 & 2 & $\begin{array}{l}\text { ICS, biological } \\
\text { activity, ELISA }\end{array}$ & $\begin{array}{l}\text { Short term } \\
\text { restimulated }\end{array}$ \\
\hline SALKLAIYKA & 56861 & $\begin{array}{l}\text { Human } \\
\text { parvovirus } \\
\text { B19 }\end{array}$ & $\begin{array}{c}\text { Noncapsid } \\
\text { protein NS-1 }\end{array}$ & HLA-Class I & 0 & 8 & $\begin{array}{c}\text { RNA/DNA } \\
\text { detection, ICS }\end{array}$ & Direct ex vivo \\
\hline TEADVQQWLTW & 63286 & $\begin{array}{l}\text { Human } \\
\text { parvovirus } \\
\text { B19 }\end{array}$ & $\begin{array}{l}\text { Non-capsid } \\
\text { protein NS-1 }\end{array}$ & HLA-B44 & 0 & 4 & ELISPOT & Direct ex vivo \\
\hline QSALKLAIYK & 52287 & $\begin{array}{l}\text { Human } \\
\text { parvovirus } \\
\text { B19 }\end{array}$ & $\begin{array}{l}\text { Noncapsid } \\
\text { protein NS-1 }\end{array}$ & HLA-Class I & 0 & 8 & ICS & Direct ex vivo \\
\hline IDTCISATFR & 25677 & $\begin{array}{l}\text { Human } \\
\text { parvovirus } \\
\text { B19 }\end{array}$ & $\begin{array}{c}\text { Noncapsid } \\
\text { protein NS-1 }\end{array}$ & HLA-Class I & 0 & 4 & ELISPOT & Direct ex vivo \\
\hline HAKALKERMV & 23542 & $\begin{array}{l}\text { Human } \\
\text { parvovirus } \\
\text { B19 }\end{array}$ & $\begin{array}{c}\text { Noncapsid } \\
\text { protein NS-1 }\end{array}$ & HLA-Class I & 0 & 4 & ELISPOT & Direct ex vivo \\
\hline GLFNNVLYH & 20861 & $\begin{array}{l}\text { Human } \\
\text { parvovirus } \\
\text { B19 }\end{array}$ & $\begin{array}{c}\text { Noncapsid } \\
\text { protein NS-1 }\end{array}$ & HLA-Class I & 0 & 4 & $\begin{array}{l}51 \text { chromium, } \\
\text { ELISPOT }\end{array}$ & Direct ex vivo \\
\hline LHTDFEQVM & 36432 & $\begin{array}{l}\text { Human } \\
\text { parvovirus } \\
\text { B19 }\end{array}$ & $\begin{array}{c}\text { Noncapsid } \\
\text { protein NS-1 }\end{array}$ & HLA-Class I & 0 & 4 & $\begin{array}{l}\text { ELISPOT, } 51 \\
\text { chromium }\end{array}$ & Direct ex vivo \\
\hline LLHTDFEQVM & 37398 & $\begin{array}{l}\text { Human } \\
\text { parvovirus } \\
\text { B19 }\end{array}$ & $\begin{array}{c}\text { Noncapsid } \\
\text { protein NS-1 }\end{array}$ & HLA-A* 02:01 & 0 & 8 & ICS & Direct ex vivo \\
\hline
\end{tabular}


TABLe 3: Continued.

\begin{tabular}{|c|c|c|c|c|c|c|c|c|}
\hline Epitope/cluster & Epitope ID & $\begin{array}{c}\text { Source } \\
\text { organism }\end{array}$ & $\begin{array}{l}\text { Source } \\
\text { protein }\end{array}$ & $\begin{array}{l}\text { MHC } \\
\text { restriction }\end{array}$ & RF score & Assay score & Assay type & $\begin{array}{c}\text { Effector } \\
\text { origin }\end{array}$ \\
\hline GLCPHCINVG & 20787 & $\begin{array}{l}\text { Human } \\
\text { parvovirus } \\
\text { B19 }\end{array}$ & $\begin{array}{l}\text { Noncapsid } \\
\text { protein NS-1 }\end{array}$ & HLA-Class I & 0 & 8 & $\begin{array}{c}\text { ICS, RNA/DNA } \\
\text { detection }\end{array}$ & Direct ex vivo \\
\hline EADVQQWLT & 11014 & $\begin{array}{l}\text { Human } \\
\text { parvovirus } \\
\text { B19 }\end{array}$ & $\begin{array}{l}\text { Noncapsid } \\
\text { protein NS-1 }\end{array}$ & HLA-Class I & 0 & 4 & $\begin{array}{l}\text { ELISPOT, } 51 \\
\text { chromium }\end{array}$ & Direct ex vivo \\
\hline RMTENIVEV & 145986 & $\begin{array}{c}\text { Human } \\
\text { parvovirus } 4\end{array}$ & ORF1 & HLA-A ${ }^{*} 02: 01$ & 0 & 12 & $\begin{array}{l}\text { Multimer/tetramer, } \\
\text { ICS }\end{array}$ & $\begin{array}{l}\text { Short term } \\
\text { restimulated, } \\
\text { direct ex vivo }\end{array}$ \\
\hline
\end{tabular}

we selected PBMC from 5 individuals infected with DENV virus and likely uninfected with TB (see methods for details) and PBMC from 5 LTBI individuals and likely uninfected with DENV. Because of the high incidence of EBV infection worldwide [24], we assumed that most if not all individuals tested would be latently infected with EBV.

PBMC were stimulated with the DENV CD8 pool, MTB CD4 pool, and EBV CD8 pool. After ex vivo stimulation, the IFN $\gamma$ response was measured by ICS (Figures 3(a)$3(d))$. The gating strategy for these experiments is presented in Figure 3(a). Representative plots of the responses for both $\mathrm{CD} 4^{+}$and $\mathrm{CD} 8^{+} \mathrm{T}$ cells are shown for a LTBI donor (Figure 3(b)) and a DENV donor (Figure 3(c)). The IFN $\gamma$ responses induced by each epitope pool in the relevant CD4/CD8 compartments for all donors tested are summarized in Figure 3(d). In the case of the MTB CD4 pool, ex vivo CD4 but not CD8 T cell responses were seen in the LTBI $(P=$ $0.004)$ and DENV donors. The reactivity was lower in the DENV donors than in the LTBI donors $(P=0.03)$. This lower, but detectable, reactivity is explained by the fact that the DENV seropositive individuals are vaccinated against MTB with $M$. bovis BCG and are likely exposed to nontuberculous mycobacteria [25]. In the case of the DENV CD8 pool, CD8 T cell responses, but not CD4, were detected in 3 out of 5 DENV donors. This ex vivo reactivity in 3 out of 5 donors is in line with what was detected in previous studies [11]. As expected, no $\mathrm{CD} 4$ responses were seen to the CD8 DENV pool, as also low CD8 and CD4 T cell reactivity was noted in the MTB donors with the DENV CD8 pool. Finally, as also expected, in both cohorts reactivity was detected against the EBV CD8 pool in CD8 but not in CD4 T cells $(P=0.004$ for LTBI and $P=0.05$ for DENV).

\section{Conclusions}

We devised a strategy that allows automatically filtering datasets to select epitopes of appropriate size, defined restriction, and assay type for use in characterizing responses to specific indications. While querying the IEDB database can also generate these sets, a certain degree of complexity in the queries and the setting of multiple parameters would be necessary. In our application, the epitope sets are automatically generated, while the user is still enabled to change the default settings to generate validated epitope sets matching specific criteria.

We further identified which epitope categories are supported by current IEDB data, and found that reference epitope sets could be produced for 43 categories with data currently available in the IEDB. The number of such categories, broadly based on previous epitope classification work [21], is undoubtedly destined to grow, allowing an ever more comprehensive study of immune responses in a broad variety of experimental systems. To further illustrate the broad applicability of the approach, we also extended our work to address autoimmune epitopes, $\mathrm{B}$ cell epitopes, and murine epitopes.

While these actual epitope sets are provided as tables within the paper, we implemented a web application to automatically generate epitope sets, based on the fact that the IEDB content is rapidly growing and new epitopes are added to the IEDB in each of its biweekly updates. We plan to continuously gather feedback on this web application from the scientific community, and to implement changes and modifications through the main IEDB website [14].

Finally, to illustrate applicability in an actual experimental setting, we selected and synthesized peptide sets corresponding to EBV, DENV, and MTB epitopes. These epitope sets were used to measure immune reactivity in human cells. The experimental testing of these epitope sets demonstrated the applicability of these sets as a valuable resource to allow detection of $\mathrm{T}$ cell responses ex vivo. As such, these sets of epitopes represent potentially valuable resources for diagnostic purposes, as well as for further detailed characterization of the immune response to specific targets of immunological interest.

\section{Conflict of Interests}

The authors declare that they have no conflict of interests in the research.

\section{Acknowledgment}

This project has been funded with federal funds from the National Institute of Allergy and Infectious Diseases, 


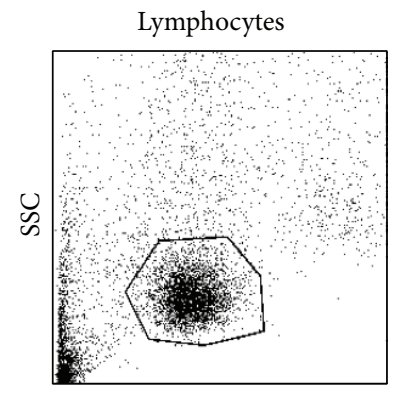

FSC

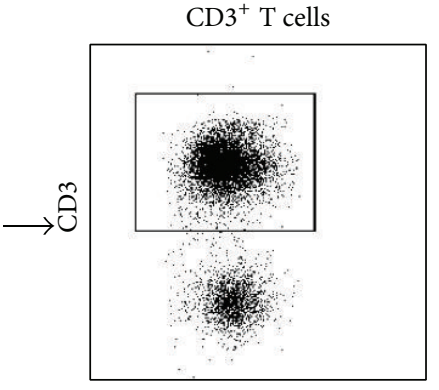

FSC

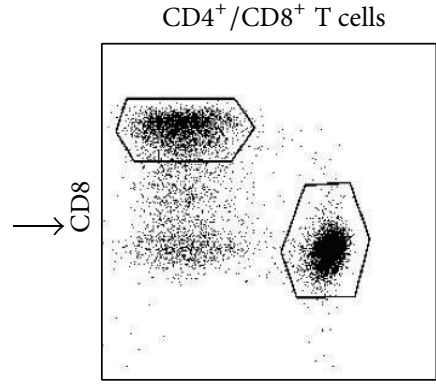

CD4

(a)

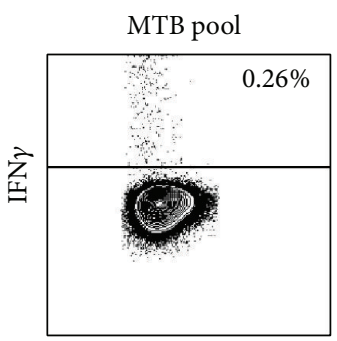

CD4

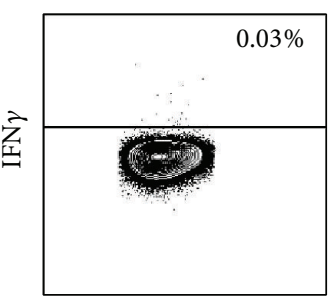

CD8

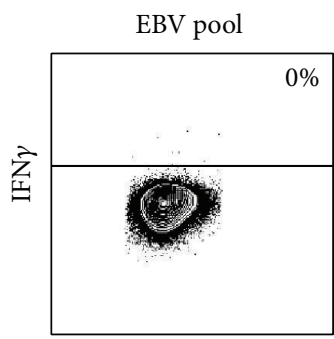

CD4

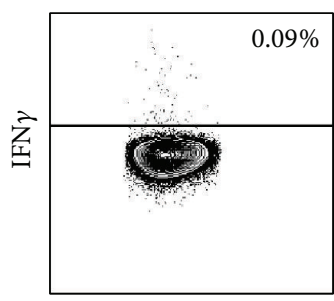

CD8

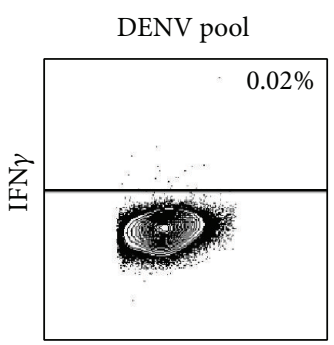

CD4

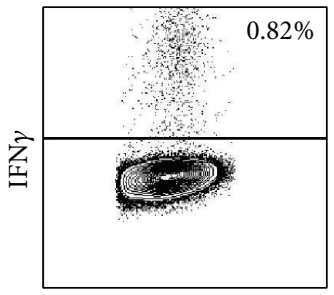

CD8

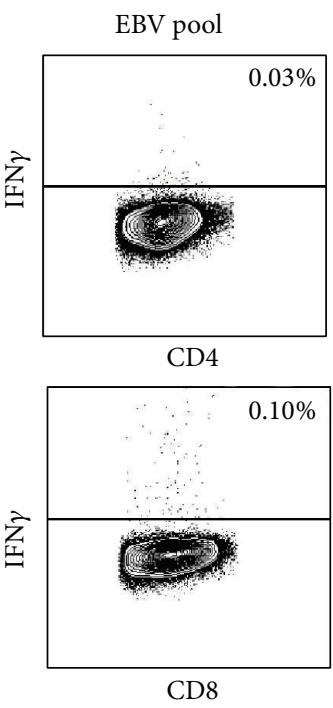

(c)

(b)

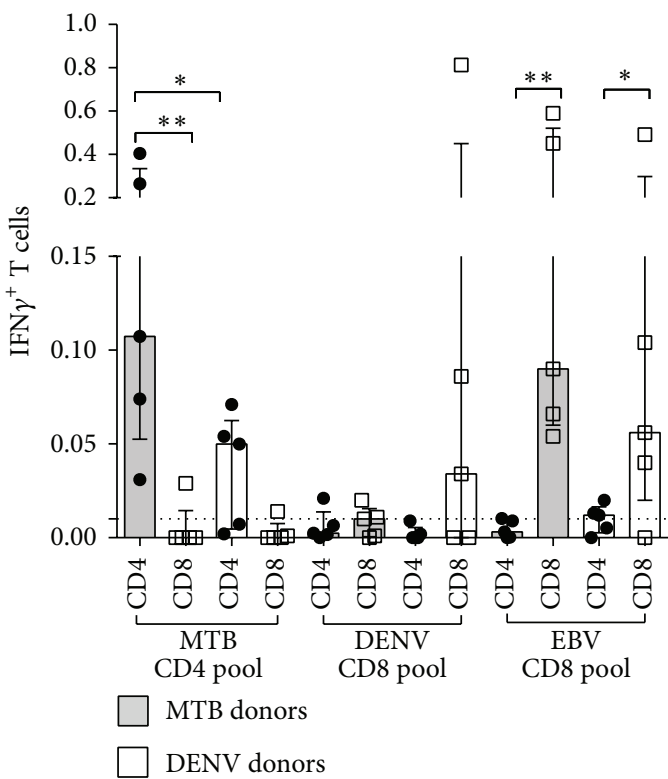

(d)

FIGURE 3: Predicted epitope pools induce a detectable ex vivo cytokine response. PBMC from donors with LTBI (MTB donor) or previously exposed to DENV were stimulated with their respective epitope pools and an EBV epitope pool. After ex vivo stimulation, the IFN $\gamma$ response was measured by ICS using flow cytometry. Gating strategy (a) and representative plots of the responses for both CD $4^{+}$and CD $8^{+} \mathrm{T}$ cells are shown for a MTB donor (b) and DENV donor (c). (d) The ICS IFN $\gamma$ responses induced by each epitope pool for all donors tested are summarized $(n=10)$. Statistical difference was determined using a one-tailed Mann-Whitney test. $\left({ }^{*} P \leq 0.05 ;{ }^{* *} P \leq 0.01\right)$. 
National Institutes of Health, and Department of Health and Human Services under Contract nos. HHSN272201200010C, HHSN272200900044C, and HHSN27220140045C and Grant no. U19 AI100275.

\section{References}

[1] D. R. Madden, "The three-dimensional structure of peptideMHC complexes," Annual Review of Immunology, vol. 13, pp. 587-622, 1995.

[2] J. Neefjes, M. L. M. Jongsma, P. Paul, and O. Bakke, "Towards a systems understanding of MHC class i and MHC class II antigen presentation," Nature Reviews Immunology, vol. 11, no. 12, pp. 823-836, 2011.

[3] C. Kurts, B. W. Robinson, and P. A. Knolle, "Cross-priming in health and disease," Nature Reviews Immunology, vol. 10, no. 6, pp. 403-414, 2010.

[4] L. Borish, "Genetics of allergy and asthma," Annals of Allergy, Asthma \& Immunology, vol. 82, no. 5, pp. 413-426, 1999.

[5] J.-M. Andrieu, S. Chen, C. Lai, W. Guo, and W. Lu, "Mucosal SIV vaccines comprising inactivated virus particles and bacterial adjuvants induce $\mathrm{CD}^{+}$T-regulatory cells that suppress SIVpositive $\mathrm{CD} 4^{+}$T-cell activation and prevent SIV infection in the macaque model," Frontiers in Immunology, vol. 5, article 297, 2014.

[6] J. Patterson-Bartlett, M. J. Levin, N. Lang, F. P. Schödel, R. Vessey, and A. Weinberg, "Phenotypic and functional characterization of ex vivo $\mathrm{T}$ cell responses to the live attenuated herpes zoster vaccine," Vaccine, vol. 25, no. 41, pp. 7087-7093, 2007.

[7] T. Prezzemolo, G. Guggino, M. P. la Manna, D. D. di Liberto, F. Dieli, and N. Caccamo, "Functional signatures of human CD4 and CD8 T cell responses to Mycobacterium tuberculosis," Frontiers in Immunology, vol. 5, article 180, 2014.

[8] A. Sette and R. Rappuoli, "Reverse vaccinology: developing vaccines in the era of genomics," Immunity, vol. 33, no. 4, pp. 530-541, 2010.

[9] C. Leisner, N. Loeth, K. Lamberth et al., "One-pot, mix-andread peptide-MHC tetramers," PLoS ONE, vol. 3, no. 2, Article ID e1678, 2008.

[10] P. Braendstrup, B. K. Mortensen, S. Justesen et al., "Identification and HLA-tetramer-validation of human $\mathrm{CD}^{+}$and $\mathrm{CD} 8^{+} \mathrm{T}$ cell responses against HCMV proteins IE1 and IE2," PLoS ONE, vol. 9, no. 4, Article ID e94892, 2014.

[11] D. Weiskopf, M. A. Angelo, E. L. De Azeredo et al., "Comprehensive analysis of dengue virus-specific responses supports an HLA-linked protective role for $\mathrm{CD}^{+}{ }^{+} \mathrm{T}$ cells," Proceedings of the National Academy of Sciences of the United States of America, vol. 110, no. 22, pp. E2046-E2053, 2013.

[12] C. Oseroff, J. Sidney, M. F. Kotturi et al., "Molecular determinants of $\mathrm{T}$ cell epitope recognition to the common Timothy grass allergen," Journal of Immunology, vol. 185, no. 2, pp. 943955, 2010.

[13] R. Vita, L. Zarebski, J. A. Greenbaum et al., "The immune epitope database 2.0," Nucleic Acids Research, vol. 38, no. 1, Article ID gkp1004, pp. D854-D862, 2009.

[14] R. Vita, J. A. Overton, J. A. Greenbaum et al., "The immune epitope database (IEDB) 3.0," Nucleic Acids Research, vol. 43, pp. D405-D412, 2015.

[15] E. J. Novak, A. W. Liu, J. A. Gebe et al., "Tetramer-guided epitope mapping: rapid identification and characterization of immunodominant CD4+ T cell epitopes from complex antigens," Journal of Immunology, vol. 166, no. 11, pp. 6665-6670, 2001.

[16] C. L. Day, N. P. Seth, M. Lucas et al., "Ex vivo analysis of human memory CD4 T cells specific for hepatitis $\mathrm{C}$ virus using $\mathrm{MHC}$ class II tetramers," The Journal of Clinical Investigation, vol. 112, no. 6, pp. 831-842, 2003.

[17] W. W. Kwok, M. Roti, J. H. DeLong et al., "Direct ex vivo analysis of allergen-specific CD $4^{+} \mathrm{T}$ cells," Journal of Allergy and Clinical Immunology, vol. 125, no. 6, pp. 1407.el-1409.el, 2010.

[18] Y. Kim, K. Vaughan, J. Greenbaum, B. Peters, M. Law, and A. Sette, "A meta-analysis of the existing knowledge of immunoreactivity against hepatitis C virus (HCV)," PLoS ONE, vol. 7, no. 5, Article ID e38028, 2012.

[19] A. Bresciani, J. Greenbaum, C. S. L. Arlehamn, A. Sette, M. Nielsen, and B. Peters, "The interplay of sequence conservation and T cell immune recognition," in Proceedings of the 5th ACM Conference on Bioinformatics, Computational Biology, and Health Informatics (BCB '14), pp. 739-743, Newport Beach, Calif, USA, September 2014.

[20] R. de Alwis and A. M. de Silva, "Measuring antibody neutralization of dengue virus (DENV) using a flow cytometry-based technique," Methods in Molecular Biology, vol. 1138, pp. 27-39, 2014.

[21] E. Seymour, R. Damle, A. Sette, and B. Peters, "Cost sensitive hierarchical document classification to triage PubMed abstracts for manual curation," BMC Bioinformatics, vol. 12, no. 1, article 482, 2011

[22] V. Davies, K. Vaughan, R. Damle, B. Peters, and A. Sette, "Classification of the universe of immune epitope literature: representation and knowledge gaps," PLoS ONE, vol. 4, no. 9, Article ID e6948, 2009.

[23] M. F. Kagnoff, "Celiac disease: pathogenesis of a model immunogenetic disease," The Journal of Clinical Investigation, vol. 117, no. 1, pp. 41-49, 2007.

[24] H. Hjalgrim, J. Friborg, and M. Melbye, "The epidemiology of EBV and its association with malignant disease," in Human Herpesviruses: Biology, Therapy, and Immunoprophylaxis, A. Arvin, G. Campadelli-Fiume, E. Mocarski, P. S. Moore, B. Roizman, and R. Whitley, Eds., Cambridge University Press, Cambridge, UK, 2007.

[25] C. S. Lindestam Arlehamn, S. Paul, F. Mele et al., "Immunological consequences of intragenus conservation of Mycobacterium tuberculosis T-cell epitopes," Proceedings of the National Academy of Sciences of the United States of America, vol. 112, no. 2, pp. E147-E155, 2015. 


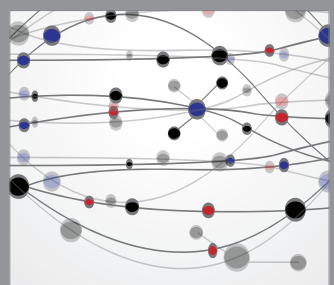

The Scientific World Journal
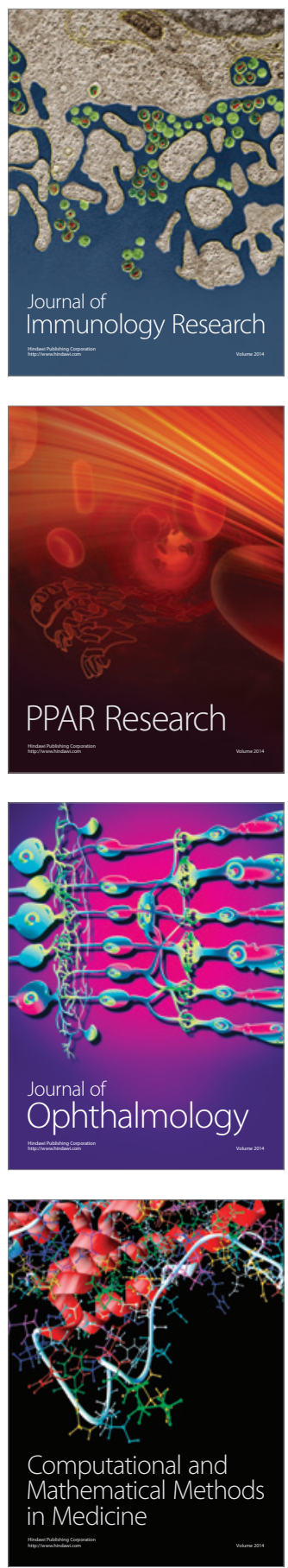

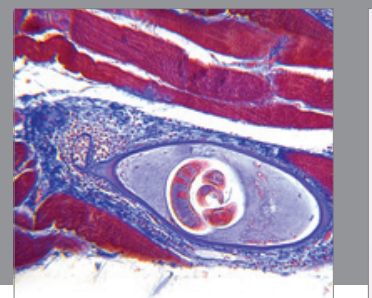

Gastroenterology

Research and Practice
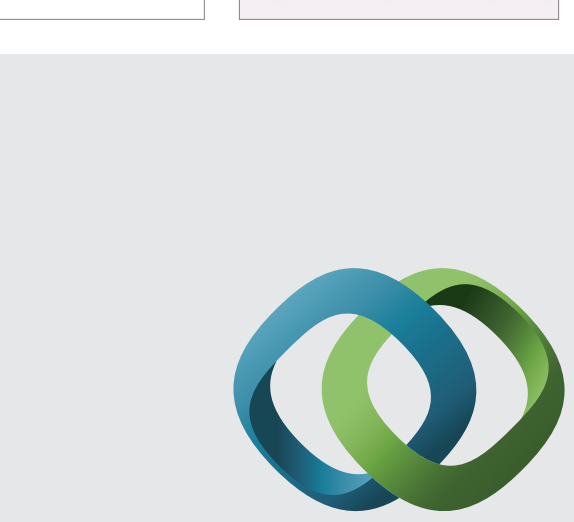

\section{Hindawi}

Submit your manuscripts at

http://www.hindawi.com
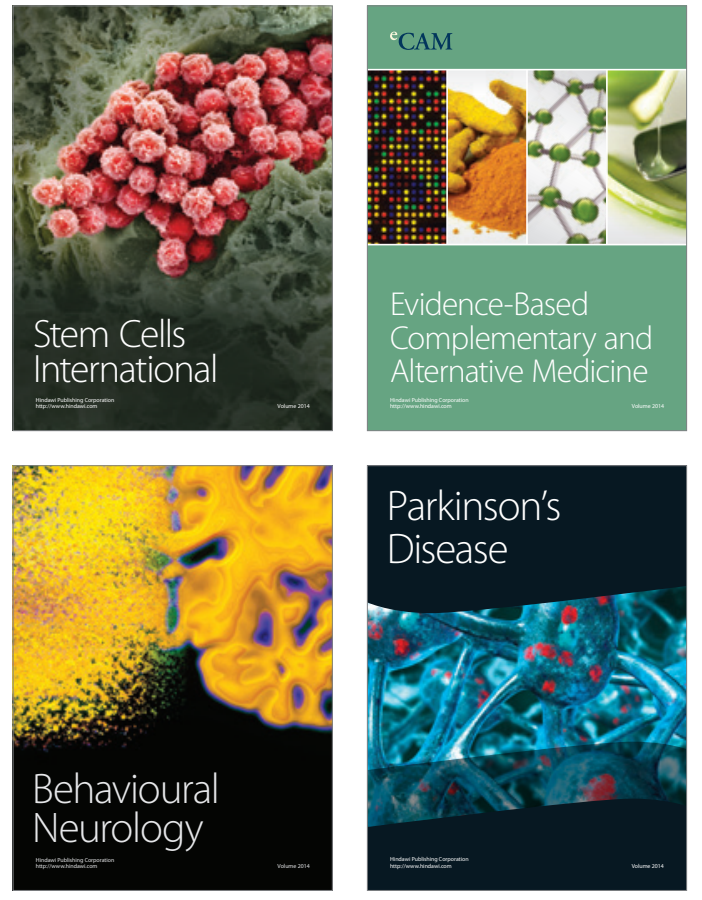
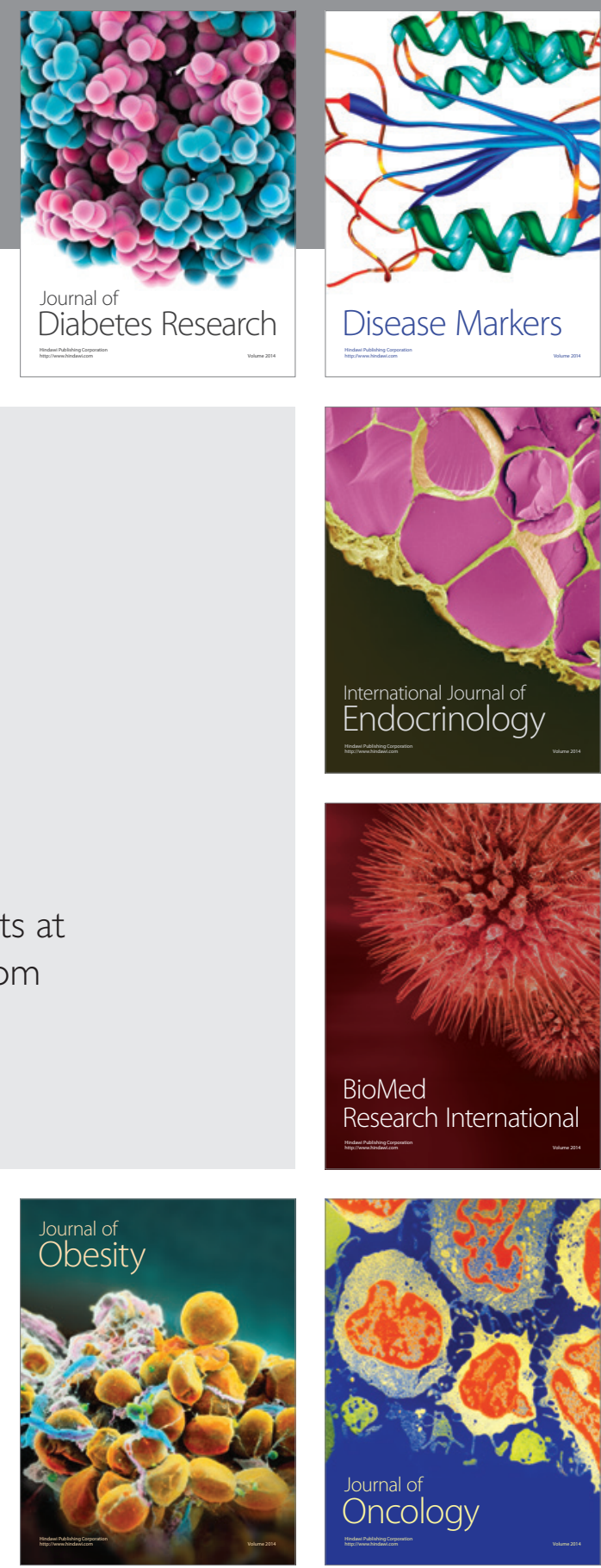

Disease Markers
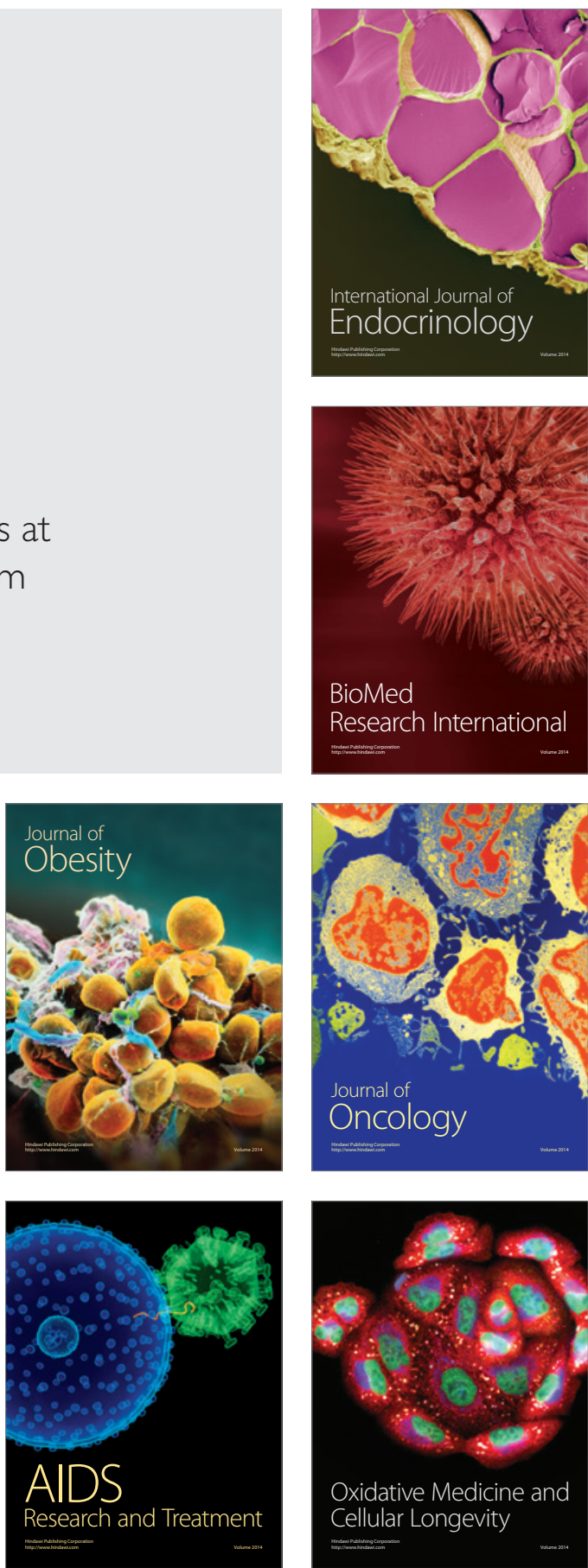